\title{
The Impact of Brand Equity on the Achievement Customers' Loyalty to the Brand: An Empirical Study of a Sample of Vodafone's Customers
}

\author{
Zaki Muhammad ABBAS BHAYA 1 \\ Basim Abbas KRAIDY JASSMY 2
}

\begin{abstract}
This study aims to discover the role of the brand equity in the process to achieving the brand loyalty from customer perspective, which is represented the dominant perspective and favored by the majority of academics and practitioners in Marketing Research, This research was focused on the study of customer-based brand equity of the opinions of customers' sample of Vodafone. The research sample included (100) customer which refers to how responsive customer to Vodafone brand. The authors examined all the variables of the questionnaire by using (factor analysis). The study is showed the role of this perspective in satisfying the desires of customers, and revealed a number of conclusions that refers the importance of the brand equity to the customers in creating brand loyalty.
\end{abstract}

KEYWORDS: brand equity, brand loyalty.

JEL CLASSIFICATION: $M 30$.

\section{INTRODUCTION}

The organizations seek to build a strong brand for the product. To be clearly distinguished, in this way the organizations will help the customers in the choosing process to meet their desires. As a result, the loyalty of the customers will be gained, which is one of the strategic objectives of the organizations. The firms invest much of resources so as to build and maintain their brands. Firms must, therefore, manage by metrics and balance short and longterm among Point of views and performance (Roll, 2009). As well most of the conceptualization of brand equity agrees with the phenomena which include the value of the product by the customer, also the association and realization of a brand name (Chaudhuri, 1995).

This study provides a clearer understanding of brand equity which directs positive impact in the brand loyalty through a deep understanding of the customer behavior .Thus, the behavioral perspective sheds light on the customer's response to the brand, either in terms of understanding or purchase. In this way; the organizations will help the Customers in the choosing process and meet their desires. As a result, the loyalty of the Customers will be gained is one of the strategic objectives of the organizations. Businesses that intend to get benefit through using the brand as a driver of business success; it must begin the process by identifying and managing the brand, in a more methodical and structured way. The brand has an effective role in the prescribed marketing policy that the organization follows whether to promote itself or its services.

\footnotetext{
${ }^{1}$ The Bucharest University of Economic Studies, Romania,_zakimohammad2008@yahoo.com

${ }^{2}$ The Bucharest University of Economic Studies, Romania, Kamalkadem1979@mu.edu.iq
} 


\section{LITERATURE REVIEW}

\subsection{Brand Equity}

One of the most important marketing concepts that has been extensively discussed by practitioners and academicians. It has become necessary for brand directors to understand and measure brand equity (Ambler, 2003). It reflects the financial and marketing value which is depending on the brand strength in the market. Comprehending of the brand leads to make it more popular and to lead to achieve the customer's satisfaction; as a result, it will be preferred by the customer rather than the other brands. One of the important components of the brand equity is loyalty which in turn, maximizes the level of importance compared to the competitors' brands as well as enables the organization to retention of customer (Pride, 2000). (Simon and Sullivan, 1993) mention that there are financial approach and Customer-based approach for measuring the value of the brand name.

Therefore a brand equity is based on the financial value is focusing on the financial effect of marketing activities on company performance (Baldauf et al., 2003). (Pride \& Ferrell, 2003, p. 299) mention that Brand equity can be defined as "the marketing and financial values linked with a brand's strength in the market including actual proprietary brand assets, brand name awareness, brand loyalty, perceived brand quality. Wood (2000) mention that it is possible in this perspective give to the brand a monetary value that can be useful for directors in case of divestiture, acquisition or merger. Estimating a financial value for the brand is surely useful but it does not assist marketers to understand the operation of building brand equity. The financial approach was viewed as a way that gave guidance to help the managers in the process of enhancement to understand of brand. Furthermore, the measures in this direction focused on brand replacement or direction stock prices (Myers, 2003).

On the other hand, the customer based brand equity approach focuses on how the Customer look to brands (Farquhar, 1989; Cobb-Walgren, 1995). brand equity according to customerbased approach usually divided into two different groups which is component of customer perceptions (e.g., brand awareness, brand associations, perceived quality) and all of them focusing on actual behavior of Customer (Washburn and Plank. 2002; Pappu, 2006, 2007). Extant literature on brand equity has focused on the perspective of cognitive psychology namely as Customer-based brand equity (Christodoulides and De Chernatony, 2008). Farjam and Hongyi (2015) conclude the customer-based brand equity (CBBE) approach is the dominant perspective and its preferred by a majority of academics and practitioners in marketing research because if a brand has no meaning or value to the customer it is ultimately meaningless to investors, manufacturers, or retailers (Cobb-Walgren et al., 1995). Motameni (1998) also mentioned this perspective is considered as a marketing perspective.

The brand that is based on the customers has many advantages, such as the long term revenue, the customer's desire to search for new distribution channels and the ability of the organization to put high prices and effectiveness of marketing communications (Keller, 2003). According to a perceptual to the customer, Keller (1993) defines customer-based brand equity as "the differential effect of brand knowledge on customer response to the marketing of the brand". Brand knowledge representing brand image (brand associations e.g. strength, uniqueness, and dominance)brand awareness (recall and recognition) also is a distinguishing side of brand knowledge and it can influence customer decisions through impact the power and design of the brand associations in the brand image. (Keller, 2003)(Agarwal, 1996) defined Brand equity is "as brand awareness and brand association have on customer response to the marketing of that brand. The marketing includes advertising, distribution, pricing and promotion as well as new products and brand extensions". 
Brand equity is the degree of differences to impact of brand information for customer responsiveness of brand (Kohli and Leuthesser, 2005). According to (Norouzi et al. 2011), brand equity can be get from customer awareness from that brand and this awareness is change by some factors affecting which is efficacious brand equity in the minds of the customers. Bovee and Thill(1992) mention that brand equity is the whole strengths within the market and its value for the organization. Furthermore it is the fundamental element which refers to the brand reliability. Researches were supporting the positive effect of brand equity on market force, on the company market share and customers' ready to pay special prices. In other words the brand equity Contribution to the achievement the future profits and long-term cash flow, sustainable competitive advantage and success of marketing (Sinha et al., 2008).

Therefore, the brand equity provides the customers with the value through backing the customers with interpretation, data processing and confidence. It also provides the organization with the value through enhancing the efficiency and effectiveness of marketing programs, brand loyalty, prices, commercial influences and the competitive advantage (Aaker, 1996).

On other hand the brand equity is the fundamental element that shows the brand reliability. It has an important role by which it can improve future earnings and long-term cash flows, sustainable competitive advantage and marketing success. The brand equity researches have approved that the brand equity has a positive impact on the marketing strength, the organization market share and the customer's willing to pay higher prices (KILIÇ, 2011).

The brands vary in strength, influence and value. There are brands that are unknown for the customers (it could be achieved by remembering or comprehending of the brand). Furthermore, we have found brands that have a high degree of acceptability, in other word, the brands most known for customers do not prevent from purchased, then there are brands that characterized by a high degree of preference. These brands have been chosen from among the other ones. They have a high degree of loyalty (Kotler and Dupree, 1997).Also its will be strengthened and maximized when the customers have positive perceptions about brand (Dalrymple and Parsons, 2000).

\subsection{Brand Loyalty}

The Companies face major challenges because of the opening up of markets and the entry of competitors, therefore, this status of the customer in front of a large number of options and the difficulty of making a decision to purchase but that the biggest challenge facing the companies is to maintain the loyalty of the customers of products and brand those products.

The brand loyalty is the customer orientation towards a certain brand. If there is a more brand loyalty there will be more purchasing of that brand product. The loyalty will make the purchasing decision much easier and minimize the time. Anyway, the loyalty level is different form brand to another. There are three levels of the brand loyalty (pride and ferller, 2000). The levels are as the following:

- Brand realization: it means that the customer understands the brand and its product.

- Brand preference: it means how degree of brand loyalty that prefer customer to other brands.

- Insisting for the brand: it means that how very much the customers are willing to have it.

The brand loyalty is an essential dimension of the Brand equity (Aker, 1992). The real loyalty goes beyond the mere frequent purchasing. Therefore, There must be a precisely correlation exam for the commitment of customers toward the brand to have a comprehensive 
understanding of the loyalty (Quester and Lin, 2003). As well the customer loyalty is the fundamental element for the long term success of the organization and its brand. It depends on granting the customers with a product or a service that desire to purchasing it and interesting for use it (Ellwood, 2002). The companies should satisfy its customers if they want to gaining customers to its brand to the. If there be a satisfaction there will has be more commitment for the brand purchasing, as a result the loyalty for the brand.

Moisescu (2005) mentioned that the brand loyalty generates a value by reducing marketing costs and benefits trade (Farjam and Hongyi, 2015). Severi and Ling (2013) has added that the brand loyalty is the essential element when it comes to the assessment of the brand in terms of the value since the brand loyalty can gain profit. Fatema et al. (2013) has indicated that the organizations will gain a competitive advantage when they have a high percentage of loyalty. So the concept of the loyalty can help the organizations to manage the customer relationships in order to create a long-term investment and profitability. Thus, the brand is a key element in making purchasing decisions and assessing the risks that related to the purchase and consumption of the product. So the brand has several dimensions that are related to the experience of the customers with the product.

The brand loyalty is considered as one of the marketing concepts which represented of major components of the marketing knowledge. The brand loyalty concept is very important in terms of the marketing strategy, especially in the current markets that are very mature and competitive. It very important to keep the customers loyal for the brand so as to the company can survive and continue. It is often very effective and efficient strategy to attract new customers (Peter and Olson, 1996). When the brand is well built, it will be able to send a positive reputation, and the customers will continue be willing to have it. The strong brand is a key factor in making purchasing decisions, the more famous brand attain a more revenue the company will have (Kotler, 2000).

The brand can build a terrific level of loyalty. The companies should not neglect this brand value. There are many ones who don't have a strong brand try to get rid of the traditional methods and adopting new ones for such as a loyalty (Cheverton, 2002). There are several activities that can make a benefit of the loyalty such as maintaining a long term performance, developing the products, concentrating on the customers, emphasize the frequent purchasing, maximizing the range of maintaining the customers, shortening the cycle purchasing and enhancing the experience of the customers as well. All these activities will make the company able to respond to the needs of its customers and to distinguish its products and services among competitors by a long term loyalty (Kaynak, et al., 2008). (Aaker, 1992) believed that the concentrating on the brand loyalty is often an effective mean for the management of the brand equity. Therefore, the business organizations have to maintain its customers and strengthen the relationship with them in order to ensure their loyalty for the brand. This can be done through assess all what would lead to satisfy the customers and their desires. The marketer should identify the characteristics of the product that made this loyalty to maintain these customers.

There are two customer loyalty dimensions; the first dimension is the behavioral dimension and the second dimension is the positional dimension (Julander et al. 1997). The behavioral dimension refers to the customer behavior of repeating the purchase and to the product preference for a long time (Bowen and Shoemaker, 1998). This dimension has been criticized since it has based on the repeating times of the purchasing behavior (Oliver, 1999). On the other hand the positional dimension refers to the position of the customer that is based on their willing for repurchasing and commitment towards the company rather than the other 
ones. It has good indicators of the customer loyalty for the organization (Getty and Thompson, 1994).

It reflects the actual behavior of the customer through trying to analyze the nature of the influences that make the individual take purchasing position. It focuses on these effects in building loyalty for the organization and its products and services. Also, this type depends on the feelings and behaviors shown by the customer towards the provided product and service (Bottomley, 2004). (Raj G. And Moberg, 1997) has mentioned that the brand loyalty is determined by the behavioral, positional perspectives and choices. While behavioral perspective is based on the amount of purchases for a certain brand, the positional perspective includes customer tastes and behaviors towards brands and the choice perspective focuses on the reasons for the purchase or factors that may affect the options. Brand loyalty definitions are experimentally searched into three main categories: Multi-domain approach, behavioral approach and positional approach (Rundle-Thiele and Bennett, 2001). (Aaker, 1991) has identified the brand loyalty. It is a situation in which reflects who likely customer will shift to another type, especially when change occurs in the brand, whether in prices or in the Product features.

From the results presented in Table (1), we find that the number of factors affecting the loyalty of the consumer to the Vodafone brand is (18) factors in the number of variables affecting the consumer loyalty to the Vodafone brand. From the table (1), there are three significant factors out of eighteen factors, because these three factors had eigenvalues greater than one. While eigenvalues for the other factors were less than one. The effect of these factors was weak and was underestimated by the interpretation and the focus only on the three significant factors in interpreting the consumer loyalty variables of the Vodafone brand. We find that these three significant factors have a high interpretation capacity. These three factors contribute to the interpretation of $(73.74 \%)$ of the total variance, a so it is very large percentage indicating the ability of these three factors in the variance of customer loyalty to the Vodafone brand.

\section{RESEARCH METHODOLOGY}

\subsection{Population and Data Collection}

The population for this paper is represented by the customers who use the service of Vodafone Company in Romania, covering (105) customers. (105) questionnaire forms were distributed and only (100) questionnaire forms returned were assessed as being usable. These questionnaire forms were suitable to conduct factor analysis.

Table 1. Demographic of Respondents

\begin{tabular}{|c|c|c|c|}
\hline Respondents & Categories & Frequency & Percentage \\
\hline Age & $20-30$ & 78 & $78 \%$ \\
& $30-40$ & 10 & $10 \%$ \\
& $40-$ & 12 & $12 \%$ \\
\hline Gender & Male & 59 & $59 \%$ \\
& Female & 41 & $41 \%$ \\
\hline Education level & College Graduate Master & 75 & $75 \%$ \\
& PhD & $15 \%$ & $10 \%$ \\
& & 10 & \\
\hline
\end{tabular}

Source: Authors 


\subsection{Analysis}

To test the relationship between the brand equity and customer loyalty of the brand, Factor analysis was conducted. To achieve this purpose, all variables in this study were included: brand equity and customer loyalty of the brand. It was determined the relationship between the variables of the study.

\subsubsection{Results and Discussions}

Table 2. Results of Eigenvalues, Variance Extracted \% and Cumulative Variance\% of Customer Loyalty to the Brand

\begin{tabular}{|l|c|c|c|}
\hline \multicolumn{1}{|c|}{ Factors } & Eigenvalues & Variance Extracted $\%$ & Cumulative Variance \% \\
\hline$F_{1}$ & 10.315 & 62.863 & 62.863 \\
\hline$F_{2}$ & 1.186 & 6.589 & 69.452 \\
\hline$F_{3}$ & 1.771 & 4.286 & 73.739 \\
\hline$F_{4}$ & 0.658 & 3.659 & 77.399 \\
\hline$F_{5}$ & 0.541 & 3.010 & 80.409 \\
\hline$F_{6}$ & 0.490 & 2.726 & 83.136 \\
\hline$F_{7}$ & 0.425 & 2.365 & 85.501 \\
\hline$F_{8}$ & 0.398 & 2.211 & 87.712 \\
\hline$F_{9}$ & 0.357 & 1.985 & 89.698 \\
\hline$F_{10}$ & 0.333 & 1.850 & 91.548 \\
\hline$F_{11}$ & 0.277 & 1.541 & 93.089 \\
\hline$F_{12}$ & 0.258 & 1.436 & 94.526 \\
\hline$F_{13}$ & 0.236 & 1.313 & 95.840 \\
\hline$F_{14}$ & 0.190 & 1.059 & 96.90 \\
\hline$F_{15}$ & 0.165 & 0.920 & 97.820 \\
\hline$F_{16}$ & 0.159 & 0.884 & 98.704 \\
\hline$F_{17}$ & 0.120 & 0.671 & 99.375 \\
\hline$F_{18}$ & 0.112 & 0.624 & 100.00 \\
\hline
\end{tabular}

Source: Authors

To determine the variables that affect the consumer loyalty of the Vodafone brand, we will depend on factor loadings greater than $(0.5)$ between variables and significant factors.

Table 3. The Factor Loading of Customer Loyalty to the Brand

\begin{tabular}{|c|c|c|c|}
\hline Variables & Factor 1 & Factor 2 & Factor 3 \\
\hline$V_{1}$ & -0.977 & -0.341 & 0.081 \\
\hline$V_{2}$ & -0.941 & -0.304 & 0.058 \\
\hline$V_{3}$ & -0.924 & -0.325 & -0.005 \\
\hline$V_{4}$ & 0.895 & -0.303 & 0.058 \\
\hline$V_{5}$ & -0.245 & 0.059 & 0.587 \\
\hline$V_{6}$ & -0.2491 & -0.232 & 0.880 \\
\hline$V_{7}$ & -0.855 & -0.169 & -0.019 \\
\hline$V_{8}$ & -0.238 & -0.871 & -0.134 \\
\hline$V_{9}$ & -0.230 & 0.095 & -0.308 \\
\hline$V_{10}$ & -0.220 & 0.044 & -0.537 \\
\hline$V_{11}$ & -0.231 & 0.745 & -0.345 \\
\hline$V_{12}$ & -0.209 & 0.270 & -0.332 \\
\hline$V_{13}$ & -0.204 & 0.379 & -0.652 \\
\hline
\end{tabular}




\begin{tabular}{|c|c|c|c|}
\hline Variables & Factor 1 & Factor 2 & Factor 3 \\
\hline$V_{14}$ & -0.811 & 0.188 & 0.262 \\
\hline$V_{15}$ & -0.832 & 0.229 & 0.321 \\
\hline$V_{16}$ & -0.246 & 0.850 & 0.318 \\
\hline$V_{17}$ & -0.258 & 0.784 & 0.110 \\
\hline$V_{18}$ & -0.200 & 0.181 & -0.113 \\
\hline
\end{tabular}

From the results shown in Table (3) can be classified the variables within Factors as follow:

- V_1(Vodafone brand comes first in my mind when I need to make a purchase decision on the service) with a factor loading of (0.977). This variable occupies the first place in effect within the first factor.

- V_2 (I can recognize the symbol or the logo of Vodafone brand immediately) with a factor loading of (0.941). This variable occupies the second place in effect within the first factor.

- V_3 (There existed services of this brand are suitable for each customers group) with a factor loading of (0.924). This variable occupies the third place in effect within the first factor.

- V_4 (I can recognize this brand among competing brands) with a factor loading of (0.895). This variable occupies the fourth place in effect within the first factor.

- V_7 (I believe this brand is upgrading its products to suit the changing consumer demands and expectations) with a factor loading of (0.855). This variable occupies the fifth place in effect within the first factor.

- V_15 (Vodafone brand services are high-quality services) with a factor loading of (0.832). This variable occupies the sixth place in effect within the first factor.

- V_14 (I am committed to Vodafone brand) with a factor loading of (0.811). This variable occupies the seventh place in effect within the first factor.

From the results presented in Table (1), there were seven variables that had a significant effect on the first factor, while the rest of the variables had a weak effect within this factor.

\section{The First Factor}

The importance of this factor comes in first in influencing the customer loyalty of the Vodafone brand, where the percentage of extracted variance of this factor is $(62.86 \%)$ out of the total variance. As for the variables included in this factor they are.

\section{The Second Factor}

This factor comes in second in influencing the consumer loyalty of the Vodafone brand, where the percentage of extracted variance of this factor is (6.58) out of the total variance. As for the variables included in this factor they are:

- $V_{8}$ (Services provided by the company in proportion to the social status and style of my personality) with a factor loading of (0.871). This variable occupies the first place in effect within the second factor.

- $\quad V_{16}$ (Vodafone brand lives up to its promise) with a factor loading of (0.850). This variable occupies the second place in effect within the second factor.

- $V_{17}$ (Vodafone brand is the best brand in its category) with a factor loading of (0.784). This variable occupies the third place in effect within the second factor.

- $V_{11}$ (In general, I see myself as a loyal customer of this brand services) with a factor loading of (0.745). This variable occupies the fourth place in effect within the second factor. 
From the results presented in Table (1), there is a set of variables that affect this factor, while the rest of the variables have a weak effect within the second factor.

This factor comes in third in influencing the consumer loyalty of the Vodafone brand, where the percentage of extracted variance of this factor is $(4.28 \%)$ out of the total variance. As for the variables included in this factor they are:

- $V_{6}$ (I think Vodafone brand is superior to other competing brands) with a factor loading of (0.880). This variable occupies the first place in effect within the third factor.

- $\quad V_{13}$ I would be willing to pay a higher price for this brand over other brands with a factor loading of (0.652). This variable occupies the second place in effect within the third factor.

- $V_{5}$ (Vodafone brand is the only brand recalled when I need to make a purchase decision on the service) with a factor loading of (0.587). This variable occupies the third place in effect within the third factor.

- $V_{10}$ (Vodafone brand is my first choice during the shopping new service) with a factor loading of (0.537). This variable occupies the fourth place in effect within the third factor.

Through this result, we find that there are four variables have a strong impact on the third factor and the rest of the variables have been minor effects cannot be focused on the interpretation within this factor. The figure (1) shows the factor loadings of the important variables associated with the three significant factors.

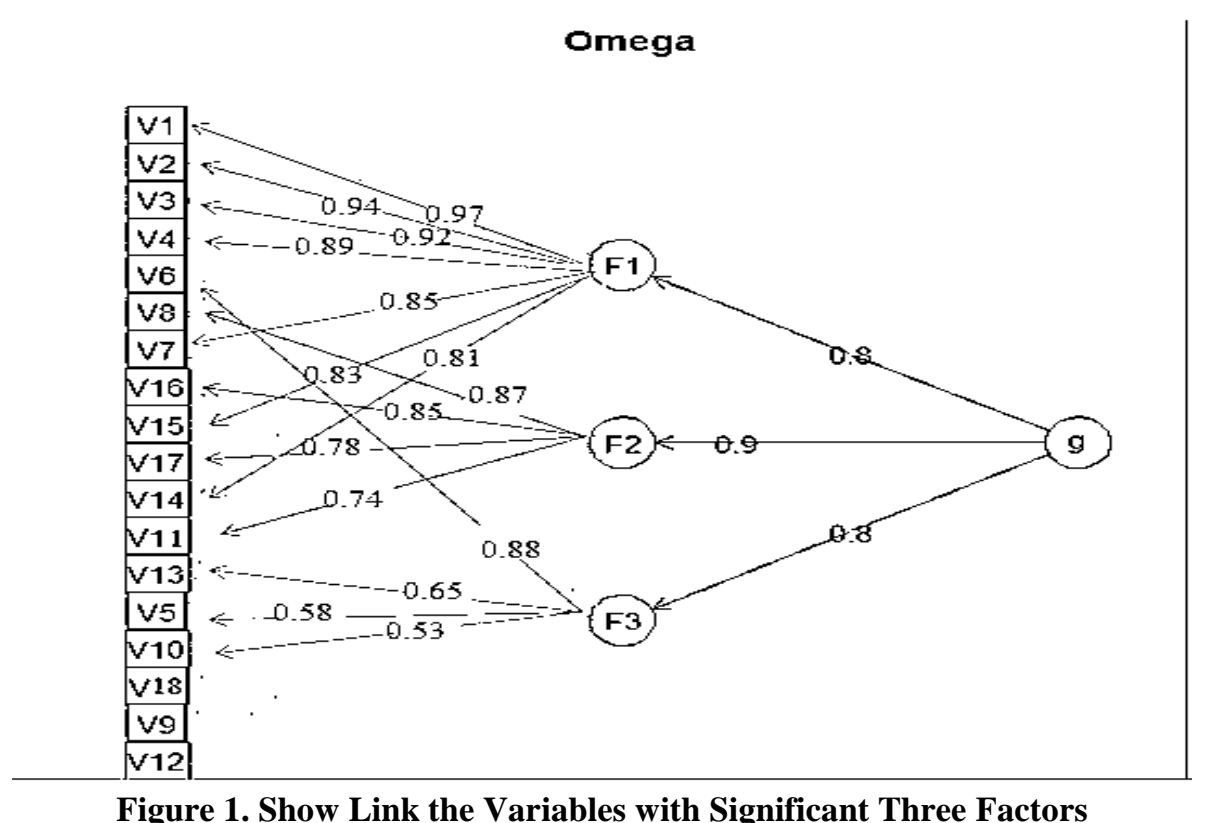

Source: Authors

From figure (1) we note that these three factors correlate closely with loyalty Consumer of Vodafone brand. These three factors include (15) significant variables that have a strong impact on customer loyalty to the Vodafone brand. However, there were three variables that had a weak and insignificant effect on consumer loyalty to the Vodafone brand:

V_9 :(I consider the company and people who stand behind the brand are very trustworthy), V_18 (Vodafone brand has excellent features)) V_12, I really like Vodafone brand services)

The importance and priority of significant variables affecting customer loyalty to the Vodafone brand can be arranged as follows: 
1- $\quad V_{1}$ (Vodafone brand comes first in my mind when I need to make a purchase decision on the service) with a factor loading of (0.977).

2- $\quad V_{2}$ (I can recognize the symbol or the logo of Vodafone brand immediately) with a factor loading of (0.941).

3- $\quad V_{3}$ (There existed services of this brand are suitable for each consumer groups) with a factor loading of (0.924).

4- $\quad V_{4}$ (I can recognize this brand among competing brands) with a factor loading of (0.895).

5- $\quad V_{6}$ (I think Vodafone brand is superior to other competing brands) with a factor loading of (0.880).

6- $\quad V_{\mathbf{8}}$ Services provided by the company in proportion to the social status and style of my personality with a factor loading of (0.871).

7- $\quad V_{7}$ (I believe this brand is upgrading its products to suit the changing consumer demands and expectations) with a factor loading of (0.855).

8- $\quad V_{16}$ (Vodafone brand lives up to its promise) with a factor loading of (0.850)

9- $\quad V_{15}$ Vodafone brand services are high-quality services. With a factor loading of (0.832).

10- $V_{14}$ (I am committed to Vodafone brand) with a factor loading of (0.811).

11- $V_{17}$ (Vodafone brand is the best brand in its category) with a factor loading of (0.784).

12- $V_{11}$ (In general, I see myself as a loyal customer of this brand services) with a factor loading of (0.745).

13- $\quad V_{13}$.(I would be willing to pay a higher price for this brand over other brands). With a factor loading of (0.652).

14- $\quad V_{5}$ (Vodafone brand is the only brand recalled when I need to make a purchase decision on the service) with a factor loading of (0.587).

15- $\quad V_{10}$ (Vodafone brand is my first choice during the shopping new service) with a factor loading of (0.537).

While the other variables had little effect on customer loyalty to the Vodafone brand. So we can delete these variables in the order of interpretation.

The following figure (2) shows the arrangement of the variables according to their effect and priority on the consumer loyalty to the Vodafone brand.

\section{Omega}

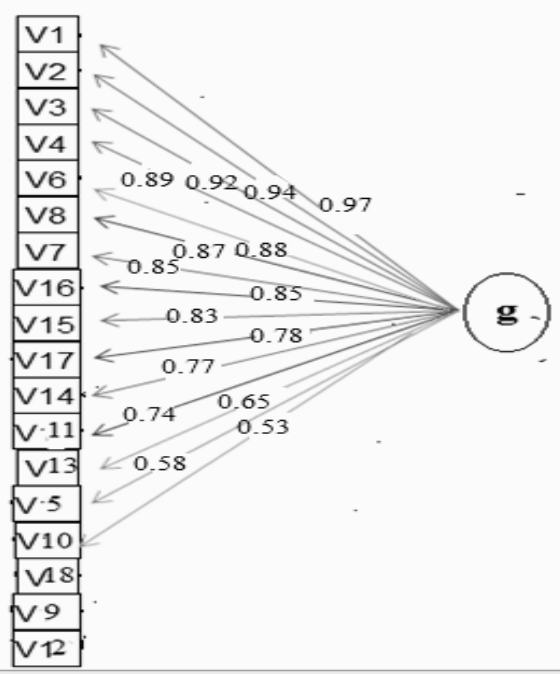

Figure 2. Arrangement of the Variables According to their Effect and Priority

Source: Authors 


\section{CONCLUSIONS}

From literature review has identified It is importance to know that building strong brand equity is important strategy for distinguish a product / service from its competitors. Through carefully designed marketing activities to build long-term brand equity. On another hand, the organizations must optimize use the available information about their brand equity in a way that strengthens the brand's performance and then managing them strongly through all customer touch points and the ability to optimize brand equity through increasing their impact on the brand and the business. In this study researchers through the literature review reached the following:

- The high value of the brand provides a group of competitive advantages such as minimizing the marketing costs because of customer loyalty. Advantage in negotiating with distributors and retailers, getting higher prices to get customer high quality, offer new products that carry the brand name because brand name associated with customer's reliability on high quality and providing a defense line which can encounter the price war.

- The concept of loyalty to the brand is the final result of all activities and plans of the organization; therefore, all factors which interpret the brand loyalty should be taken into consideration.

- The goal of many business organizations is to have brand that has good image and quality. There is a need to meet the desires and preferences of Customers at the required quality, which represents the perceptions held by the customer about the quality of products.

- Brand awareness is an important indicator of Customer knowledge about the brand and as well as the brand presence strength in the minds of Customers.

- Studying Customer behavior sees that the brand image is the product key to success. It reflects the Customer sentiment and attitude towards the brand. So the organization should reinforce this image through its marketing activities.

- The results showed that there are three strong and significant factors that influence on consumer loyalty to the Vodafone brand. We find that these three factors were able to explain $(73.74 \%$ ) of the total variance, while the unexplained discrepancy is due to the rest of the factors excluded (unimportant) and has a weak impact on consumer loyalty to the Vodafone brand.

- The results showed that (15) variables had a clear effect on consumer loyalty to the Vodafone brand with varying importance and priority. However, we find there are three variables that have a weak effect on consumer loyalty. Therefore, these three variables can be dispensed for the purposes of interpretation and focus on the study of (15) variables.

\section{REFERENCES}

Aaker D., A. (1996). Building Strong Brand. Library of Congress Cataloging-in-Publication Data, New York

Aaker, D. A. (1991). Managing Brand Equity: Capitalizing on the Value of a Brand Name New York: The Free Press

Aaker, D. A. (1992). The value of brand equity. Journal of business strategy, 13(4), 27-32

Agarwal, M. K., \& Rao, V. R. (1996). An empirical comparison of consumer-based measures of brand equity. Marketing letters, 7(3), 237-247

Ambler, T. (2003). Marketing and the bottom line: the marketing metrics to pump up cash flow. Pearson Education 
Baldauf, A., Cravens, K. S., \& Binder, G. (2003). Performance consequences of brand equity management: evidence from organizations in the value chain. Journal of product \& brand management, 12(4), 220-236

Bottomley, M. (2004). Unlocking the value of customer relationships through emotional loyalty. CRM Project. (5), 78-90

Bovée, C. L. \& Thill, J. V. (1992). Study guide to accompany Marketing. McGraw-Hill

Bowen, J. \& Shoemakers, S. (1998). Loyalty a strategic commitment, Cornell H.R.A. Quarterly, 2.pp. 12

Cheverton, P. (2002). How Come Your Brand Isn't Working Hard Enough? The Essential Guide to Brand Management (Vol. 3). Kogan Page Publishers

Christodoulides, G., \& De Chernatony, L. (2010). Consumer-based brand equity conceptualization and measurement: A literature review. International journal of research in marketing, 52(1), 43-66

Christodoulides, G., Cadogan, J. W., \& Veloutsou, C. (2015). Consumer-based brand equity measurement: lessons learned from an international study. International Marketing Review, 32(3/4), 307-328

Chaudhuri, A., (1995). Brand equity or double jeopardy? Journal of product \& brand management, 4(1), 26-32

Cobb-Walgren, C. J., Ruble, C. A., \& Donthu, N. (1995). Brand equity, brand preference, and purchase intent. Journal of advertising, 24(3), 25-40

Dalrymple, D. J., \& Parsons, L. J. (2000). Marketing management: text and cases. Wiley

Ellwood, I. (2002). The essential brand book: Over 100 techniques to increase brand value. Taylor \& Francis US

Farjam, S., \& Hongyi, X. (2015). Reviewing the concept of brand equity and evaluating consumer-based brand equity (CBBE) models. International Journal of Management Science and Business Administration, 1(8), 14-29

Farquhar, P. H. (1989). Managing brand equity. Marketing research, 1(3)

Fatema, M., Azad, M. A. K., \& Masum, A. K. M. (2015). Impact of Brand Image and Brand

Loyalty in Measuring Brand Equity of Islami Bank Bangladesh Ltd. Asian Business Review, 2(1), 42-46

Getty, J. M., \& Thompson, K. N. (1995). The relationship between quality, satisfaction, and recommending behavior in lodging decisions. Journal of Hospitality \& Leisure Marketing, 2(3), 3-22

Julander, C., Magi, A., Jonsson, J., \& Lindqvist, A. (1997). Linking customer satisfaction to financial performance data. Advancing service quality: A global perspective, 301-310.

Keller, K. L. (1993). Conceptualizing, measuring, and managing customer-based brand equity. The Journal of Marketing, 1-22

Keller, K. L. (2003). Brand synthesis: The multidimensionality of brand knowledge. Journal of consumer research, 29(4), 595-600

Kiliç, S. (2011). Relationship between global marketing and brand equity: The case of BAKTAT. International Journal of Humanities and Social Science, 1 (13)

Kohli, C. S., Harich, K. R., \& Leuthesser, L. (2005). Creating brand identity: a study of evaluation of new brand names. Journal of business research, 58(11), 1506-1515

Kotler, P. (2000). Marketing management: The millennium edition. Marketing Management, 23(6), 188-193 
Kotler, P., \& Dupree, J. (1997). Marketing Management: Analysis, Planning, Implementation, and Control, Test Item File. Prentice Hall

Moisescu, O. I. (2005). The concept of brand equity-A comparative approach

Myers, C. A. (2003). Managing brand equity: a look at the impact of attributes. Journal of product \& brand management, 12(1), 39-51

Norouzi, M., Rahmandoust, M., Barkhordar, E., Shah, I. M., \& Norouzi, N. (2011). Customer knowledge management-oriented benchmarking based on AHP technique: Case study in two shopping centers in Iran. Australian Journal of Basic and Applied Sciences, 5(10), 1074-1080

Oliver, R. L. (1999). Whence consumer loyalty? The Journal of Marketing, 33-44.

Pappu, R., Quester, P. G., \& Cooksey, R. W. (2006). Consumer-based brand equity and Country-of-origin relationships: some empirical evidence. European Journal of marketing, 40(5/6), 696-717.

Peter, J. P., Olson, J. C., \& Grunert, K. G. (1999). Consumer behavior and marketing strategy.

Pride, W. M., \& Ferrell, O. C. (2000). Marketing concepts and strategies. Boston: Houghton Mifflin.

Quester, P., \& Lin Lim, A. (2003). Product involvement/brand loyalty: is there a link? Journal of product \& brand management, 12(1), 22-38.

Raj G. Javalgi, R., \& Moberg, C. R. (1997). Service loyalty: implications for service providers. Journal of services marketing, 11(3), 165-179.

Roll, M. (2009). The metrics of branding, brand equity. On-line. Available: https://www.brandingstrategyinsider.com/

Rundle-Thiele, S., \& Bennett, R. (2001). A brand for all seasons? A discussion of brand loyalty approaches and their applicability for different markets. Journal of Product \&Brand Management, 10(1), 25-37.

Severi, E., \& Ling, K. C. (2013). The mediating effects of brand association, brand loyalty, brand image and perceived quality on brand equity. Asian Social Science, 9(3), 125.

Simon, C. J., \& Sullivan, M. W. (1993). The measurement and determinants of brand equity: A financial approach. Marketing science, 12(1), 28-52.

Sinha, A., Gazley, A., \& Ashill, N. J. (2008). Measuring customer based brand equity using hierarchical Bayes methodology. Australasian Marketing Journal (AMJ), 16(1), 3-19.

Washburn, J. H., \& Plank, R. E. (2002). Measuring brand equity: An evaluation of a consumer-based brand equity scale. Journal of Marketing Theory and Practice, 10(1), 46-62.

Wood, L. (2000). Brands and brand equity: definition and management. Management decision, 38(9), 662-669. 


\section{APPENDIX: The questionnaire}

Dear respondent,

This questionnaire is for the purpose of completing the research entitled "The impact of the brand equity in achievement of the customer loyalty to the brand: an empirical study of the opinions of customers' sample of Vodafone Company", the questions simply require you to choose an answer from a list of options and then tick $(\sqrt{ })$ for your corresponds for choice. We ask your cooperation in answering the questions, and giving opinions and proposals to get into more useful results with the assurance that this information will be used for the purposes of scientific research.

\section{Section1: General information}

1 - Age

20-30

$30-40$

$40-$

\section{2 - Gender}
Male
Female

\section{3 - Educational level}

college graduate

master degree

$\mathrm{PhD}$

\section{Section 2: The questions}

\begin{tabular}{|c|c|c|c|c|c|c|}
\hline & Statement & $\begin{array}{c}1 \\
\text { SD }\end{array}$ & 2 & 3 & 4 & $\begin{array}{c}\mathbf{5} \\
\mathrm{SA}\end{array}$ \\
\hline V1 & $\begin{array}{l}\text { Vodafone brand comes first in my mind when I need to make } \\
\text { a purchase decision on the service }\end{array}$ & & & & & \\
\hline V2 & $\begin{array}{l}\text { I can recognize the symbol or the logo of Vodafone brand } \\
\text { immediately }\end{array}$ & & & & & \\
\hline V3 & $\begin{array}{l}\text { There existed services of this brand are suitable for each consumer } \\
\text { groups }\end{array}$ & & & & & \\
\hline V4 & I can recognize this brand among competing brands & & & & & \\
\hline V5 & $\begin{array}{l}\text { Vodafone brand is the only brand recalled when I need to make } \\
\text { a purchase decision on the service }\end{array}$ & & & & & \\
\hline V6 & I think Vodafone brand is superior to other competing brands & & & & & \\
\hline V7 & $\begin{array}{l}\text { I believe this brand is upgrading its products to suit the changing } \\
\text { consumer demands and expectations }\end{array}$ & & & & & \\
\hline V8 & $\begin{array}{l}\text { Services provided by the company in proportion to the social status } \\
\text { and style of my personality }\end{array}$ & & & & & \\
\hline V9 & $\begin{array}{l}\text { I consider the company and people who stand behind the brand } \\
\text { are very trustworthy }\end{array}$ & & & & & \\
\hline V10 & Vodafone brand is my first choice during the shopping new service. & & & & & \\
\hline
\end{tabular}




\begin{tabular}{|c|c|c|c|c|c|c|}
\hline \multicolumn{2}{|r|}{ Statement } & $\mathbf{1}$ & 2 & 3 & 4 & $\begin{array}{c}5 \\
\text { SA }\end{array}$ \\
\hline V11 & In general, I see myself as a loyal customer of This brand service & & & & & \\
\hline V12 & I really like Vodafone brand services & & & & & \\
\hline V13 & $\begin{array}{l}\text { I would be willing to pay a higher price for this brand over other } \\
\text { brands }\end{array}$ & & & & & \\
\hline V14 & I am committed to Vodafone brand & & & & & \\
\hline V15 & Vodafone brand services are high-quality services & & & & & \\
\hline V16 & Vodafone brand lives up to its promise & & & & & \\
\hline V17 & Vodafone brand is the best brand in its category & & & & & \\
\hline V18 & Vodafone brand has excellent features & & & & & \\
\hline
\end{tabular}

